.

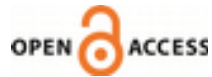

Research Article

\section{Selection criteria of some advance lines of sesame by the study of correlation and path coefficient analysis}

\author{
Barnali Roy ${ }^{1^{*}} \&$ Amit Kumar Pal ${ }^{2}$ \\ ${ }^{1}$ Department of Botany, Kanchrapara College, Kanchrapara, 743 145, West Bengal, India \\ ${ }^{2}$ Microbiology Research Laboratory, Department of Botany, University of Kalyani, Kalyani 741 235, West Bengal, India
}

\section{Article history}

Received: 03 May2019

Accepted: 18 July 2019

Published: 31 July 2019

\section{Publisher}

Horizon e-Publishing Group

\author{
*Correspondence \\ Barnali Roy \\ Wbarnaliroy barnali@yahoo.com
}

\begin{abstract}
Sesame (Sesamum indicum L.) is one of the major oil yielding plant in India, but the production of sesame seed is very low. Now it is necessary to establish the selection criteria that directly or indirectly increase the seed yield per sesame plant. In this study, freshly harvested seeds of 21 stable advance lines of sesame and their 8 parents such as R-9, B-14, B-9, B-67, T-12, IDP-51, IET-2, HT-1 were taken to evaluate the selection criteria for higher seed yield. The results indicated that number of branches/plant, number of capsule/plant, number of seeds/capsule and 100 seed weight were strongly related with sesame yield. Thus, selection of advance lines of sesame, that have higher seed yield, can be done on the basis of number of branches/plant, number of seeds/capsule, 100 seed weight and harvest index. Moreover, these traits may be employed as the selection criteria for the betterment of sesame seed yield in future agricultural system.
\end{abstract}

Keywords: Sesame; selection criteria; genotypic correlation; phenotypic correlation; pathcoefficient analysis

Citation: Roy B, Pal AK. Selection criteria of some advance lines of sesame by the study of correlation and path coefficient analysis. Plant Science Today 2019; 6(3):356-359. https://doi.org/10.14719/pst.2019.6.3.565

\begin{abstract}
Copyright: ( ) Roy \& Pal (2019). This is an open-access article distributed under the terms of the Creative Commons Attribution License, which permits unrestricted use, distribution, and reproduction in any medium, provided the original author and source are credited (https://creativecommons.org/licenses/by/4.0/).
\end{abstract}

Indexing: Plant Science Today is covered by Scopus,Web of Science, BIOSIS Previews, ESCI, CAS, AGRIS, CABI, Google Scholar, etc. Full list at http://www.plantsciencetoday.online

\section{Introduction}

Economic yield of a crop, being the most complex parameter, is generally observed to be associated with different component characters. Each of which is inter-related among themselves. Knowledge on different attributes related to yield of a plant which can effectively be utilized for selection of desired improvement in seed yield.

The various uses of sesame (Sesamum indicum L., family: Pedaliaceae) seeds in India country are very popular from ancient time. Though India is one of the major sesame producers in the world, the production of sesame seed is very low (1). In this background, we need to focus on the breeding efforts in sesame as well as good agronomic practices for increased production.

Sesame seeds for its high quality oil, protein, minerals and antioxidants $(2,3)$ used as raw food and also used to produce sweets in confectionery and bakery products (4). Sesame 
seeds also used in the preparation of soap, perfume and in the preparation of vegetable oil (5). It contains different antioxidants such as sesamin, sesamolin and sesamol. It also exerts some beneficial health properties including antioxidant activity, antihypertensive, hypolipidemic, anticarcinogenic, free radical scavenging, neuroprotective and antimutagenic properties (6-9).

Sesame is one of the most important oil seed crops in India. Although, India ranks first in sesame cultivated area (1.86 million ha) and second in its production $(6,36,000 \mathrm{Mt})$ next only to Myanmar (10), sesame production is not sufficient in comparison with the other oilseed crops such as soybean, peanut and sunflower. So, breeding programmes have to be formulated for better yield (11).

The breeding process in sesame is very difficult and the seed yield is related with several factors both directly and indirectly including environmental factors (12). The various yield attributing characters of sesame are strongly related among themselves (13).

Selection criteria, mainly based on yield, are not effective. Path coefficient analysis provides the selection on the basis of direct and indirect effects rather than the selection for yield per plant (14). Path coefficient analysis provides an effective means of separation of direct effects from indirect effects that helps the selection (15) in efficient ways.

\section{Materials and Methods}

The 21 advance lines along with their 8 parents (2) were grown in randomised block design with three replications in a five rows plot for each genotype of $5 \mathrm{~m}$ length for consecutive three years in pre-kharif season. Previously it was reported by the authors that there are significant diversity in different seed mineral contents viz. calcium (Ca), phosphorus (P), manganese (Ma), zinc (Zn), copper (Cu) and iron (Fe) among majority of 21 advance lines along with 8 parents of sesame (2). Plant heights were observed at 30, 60 and 80 days after germination (DAG) and at harvest, root length (cm), vegetative dry weight (g) and average leaf area index (LAI) were observed at 30 and 60 DAG. Number of branches/plant, days to 50\% flowering, capsules/plant, no. of seeds/capsules, 100 seed weight (g) (average weight of 100 randomly collected seeds), harvest index (HI) and seed yield/ plant (g) were also observed. Phenotypic and genotypic correlation were computed (16). Genotypic correlations were used for computation of path analysis of seed yield/plant (17).

LAI= Total leaf area (LA)/ Ground area (GA)

where $\pi r^{2} ; \mathrm{r}=\mathrm{D} / 2, \mathrm{D}=$ Diameter in $\mathrm{cm}$

$\mathrm{HI}=$ Economical yield (g)/ Biological yield (g).
Total vegetative dry weight is the sum of root, shoots and leaves of five randomly selected plants for each genotype per replication were oven dried at $50{ }^{\circ} \mathrm{C}$ for $16-18$ hrs till a constant weight and the average were computed for each genotype. The average value for no. of branches per plant and no. of capsule per plant were computed on the basis of five plants/genotype/ replication. Length of the capsules (cm) was measured of randomly selected 15 capsules/plant, 5 each from base, middle and top of the plant.

Seed viability of different varieties was calculated for further experiments by observing seed germination tests. Seed germination percentage in all the sesame lines were between $80-90 \%$. Seeds were collected from seed collection centre of Bidhan Chandra Krishi Viswavidyalaya, India.

\section{Results and Discussion}

The estimated genotypic and phenotypic correlation coefficient (r) of different growth and yield attributes are presented in Supplementary Table 1. In general, the genotypic correlation coefficient were higher than the phenotypic correlation coefficient indicating the masking effect of environment for total expression of the genotypes. Similar kind of information was reported in sesame also (18).

Significant positive correlation was recorded for seed yield with all the characters excepting days to $50 \%$ flowering and plant height and root length at 30 DAG. Similar observations were reported by Sankar and Kumar for plant height, branch number, capsule number, seed weight, harvest index, root length and dry weight at 40 DAG (8). It was reported that the first four attributes viz. plant height, branch number; capsule number and seed weight were related with yield $(8,14)$. Plant height at all the stages were found to be significantly and positively associated with all other characters except for plant height at 30 DAG with number of seeds / capsule, seed weight \& seed yield/ plant and for plant height at 60 DAG as well as at harvest with seed weight.

Number of capsules/plant, length of capsule as well as harvest index exhibited positive and significant association $(p<0.05)$ with all the traits excepting root length at 30 DAG for all the cases and days to $50 \%$ flowering for no. of capsules/plant and harvest index only. Number of branches/plant, LAI, root length at 60 DAG and plant height at 80 DAG were the only traits which exhibited significant and positive association with all the characters studied of which the highest value (0.915) was recorded between plant height and root length at 60 DAG. Number of seeds/capsules was also significantly and positively associated with all other characters excepting 
plant height and root length at 30 DAG and days to $50 \%$ flowering. Although association of seed weight was significant and positive for a large number of attributes, a significant negative association was however, noted with root length at 30 DAG.

The estimation of correlation coefficient mostly indicated the degree and direction of association among different attributes only but never produce the background casual basis of such association. This is one of the reasons for the failure made within the utility of selection indices.

In breeding of such oil seed crop path coefficient analysis is very useful to determine the direct influence of one variable on another that can separates the correlation coefficients into direct effect $(8,18)$. Selection mainly based on yield is not effective. Path coefficient analysis provides the selection on the basis of direct and indirect effects rather than the selection for yield per se alone (14).

The results of path coefficient based on the genotypic correlation coefficient is presented in Supplementary Table 2. The highest direct contribution on seed yield/plant was noted by root length at 60 DAG followed by LAI, number of branches /plant, number of seeds/capsule and number of capsules/plant. The direct effect in negative direction was exerted through harvest index, seed weight, plant height at 60 and 80 DAG, root length at $30 \mathrm{DAG}$ and vegetative dry weight at 60 DAG, though the indirect effect of both seed weight and HI via LAI, number of capsules/plant, number of seeds / capsule and plant height and root length at 60 DAG were high indicating the importance of seed yield per plant through these attributes in the selection programme. The total indirect effects were in considerable amount against 100 seed weight, seeds/capsule, capsule length, capsules/plant and number of branches/plant which indicated that the selection of sesame lines for higher seed yield potentiality would effectively be made on the basis of those characters also.

The number of seeds per capsule had positive direct effect on seed yield (19). Negative direct effect of root weight at 40 days of age, capsules on main branch and seed weight on seed yield/plant was also reported, where as the total effects contributed by them were positive (20). The residual effect in negative direction obviously meant for the inclusion of all the parameters sufficient for the path analysis.

The genotypic correlation coefficient were higher than the phenotypic correlation coefficient indicating the masking effect of environment for total expression of the genotypes. Significant $(p<0.05)$ positive correlation was recorded for seed yield with all the characters excepting days to $50 \%$ flowering and height and root length at 30 DAG. Similar type of correlation was observed during seed yield and other characters (21). Number of capsules/ plant, length of capsule as well as harvest index exhibited positive and significant association with all the traits excepting root length at $30 \mathrm{DAG}$ and days to $50 \%$ flowering. Number of branches/ plant, LAI, root length at 60 DAG and plant height at 80 DAG were the only trait which exhibited and positive association with all the characters studied of which the highest value (0.915) was reached between plant height and root length at 30 DAG and days to 50\% flowering. The highest direct contribution on seed yield/plant by number of branches/plant, number of capsule/ plant and number of seeds/ capsule was established in this study. The indirect effect of 100 seed weight and HI via LAI, number of capsule per plant, number of seeds/ capsule were high indicating the importance of seed yield/plant through these attributes in selection programme. The total indirect effects were in considerable amount against 100 seed weight, seeds/ capsule, capsule length, no. of capsules/plant and number of branches/plant which indicated that the selection of sesame lines for higher seed yield potentially would effectively be made on the basis of those characters also.

\section{Conclusion}

Path coefficient analysis in our study indicates that selection of advance lines with higher seed yield can be made by different plant agronomic traits. The overall results shows that number of branches/plant, number of capsule/plant, number of seeds/capsule, 100 seed weight were the most contributing characters on sesame yield. considering both direct effects and indirect effects, selection of advance lines with higher seed yield would effectively be made based on number of branches/plant, number of seeds/capsule, 100 seed weight and harvest index. So these traits may be used as selection criteria in future breeding programme for the improvement of seed yield of sesame.

\section{Authors' contributions}

BR conducted the whole experiment, hypothesized the paper concept, designed the experiment and collected the data. AKP supported in the experimental works, writing the manuscript and performed statistical analysis.

\section{Conflict of interest}

The authors have no conflict of interest.

\section{Acknowledgement}

The authors would like to acknowledge the financial help from DST-PURSE programme of Department of Science and Technology, Government of India. 


\section{References}

1. FAOSTAT. Food and Agriculture Organization of the United Nations [online] Available at: http://faostat.fao.org/site/339/default.aspx accessed on December 12, 2016.

2. Roy B, Pal AK. Evaluation of Nutrient Content of Some Advance Lines of Sesame Seeds. International Journal of Pharmacy and Biological Sciences 2019; 9 (1): 1174-1180. https://doi.org/10.21276/ijpbs.2019.9.1.150

3. Arslan Ç, Uzun $B$, Ülger $S$, İlhan Çağırgan $M$. Determination of oil content and fatty acid composition of sesame mutants suited for intensive management conditions. Journal of the American Oil Chemists' Society 2007; 84(10):917-20. https://doi.org/10.1007/s11746-007-1125-6

4. Pastorello EA, Varin E, Farioli L, Pravettoni V, Ortolani C, Trambaioli C, Fortunato D, Giuffrida MG, Rivolta F, Robino A, Calamari AM. The major allergen of sesame seeds (Sesamum indicum) is a $2 \mathrm{~S}$ albumin. Journal of Chromatography B: Biomedical Sciences and Applications 2001; 756(1-2):85-93. https://doi.org/10.1016/S0378-4347(01)00073-1

5. Khan NU, Akbar M, Sabir KM, Iqbal S. Characters association and path coefficient analysis in sesame (Sesamum indicum L.). Journal of Biological Science 2001; 1:99-100. https://doi.org/10.3923/jbs.2001.99.100

6. Hou RC, Huang HM, Tzen JT, Jeng KC. Protective effects of sesamin and sesamolin on hypoxic neuronal and PC12 cells. Journal of Neuroscience Research 2003; 74(1):123-33. https://doi.org/10.1002/jnr.10749

7. Noguchi T, Ikeda K, Sasaki Y, Yamamoto J, Yamori Y. Effects of vitamin E and sesamin on hypertension and cerebral thrombogenesis in stroke-prone spontaneously hypertensive rats. Clinical and Experimental Pharmacology and Physiology 2004; 31:S24-6. https://doi.org/10.1111/j.1440-1681.2004.04103.x

8. Sankar PD, Kumar CR. Character association and path coefficient analysis in sesame (Sesamum indicum L.). Agricultural Science Digest 2003; 23(1), pp.17-19.

9. Williamson KS, Morris JB, Pye QN, Kamat CD, Hensley K. A survey of sesamin and composition of tocopherol variability from seeds of eleven diverse sesame (Sesamum indicum L.) genotypes using HPLC-PAD-ECD. Phytochemical analysis 2008; 19(4):311-22. https://doi.org/10.1002/pca.1050

10. FAOSTAT. http://faostat.fao.org. 2013.
11. Furat S, Uzun B. The use of agro-morphological characters for the assessment of genetic diversity in sesame (Sesamum indicum L.). Plant Omics 2010; 3(3):8591.

12. Rauf S, Khan MT, Sadaqat HA, Khan AI. Correlation and path Co-efficient analysis of yield components in cotton (Gossypium hirsutum L) International Journal of Agricultural Biology 2004; 6:686-688.

13. Bidgoli AM, Akbari GA, Mirhadi MJ, Zand E, Soufizadeh S. Path analysis of the relationships between seed yield and some morphological and phenological traits in safflower (Carthamus tinctorius L.). Euphytica 2006; 148(3):261-8. https://doi.org/10.1007/s10681-005-9019-x

14. Kumar KB, Vivekanandan P. Correlation and path analysis for seed yield in sesame (Sesamum indicum L.). Electronic Journal of Plant Breeding 2009; 1(1):70-3.

15. Sumathi P, Muralidharan V, Manivannan N. Trait association and path coefficient analysis for yield and yield attributing traits in sesame (Sesamum indicum L). Madras Agricultural Journal 2007; 94(7/12):174-8.

16. Singh RK, Chaudhary BD. Biometrical Methods in Quantitative Genetic Analysis. Kalyani Publishers, New Delhi, 1985.

17. Dewey DR, Lu KA. Correlation and Path-Coefficient Analysis of Components of Crested Wheatgrass Seed Production. Agronomy journal 1959; 51(9):515-8. https:// doi.org/10.2134/agronj1959.00021962005100090002x

18. Parameshwarappa SG, Palakshappa MG, Salimath PM, Parameshwarappa KG. Studies on genetic variability and character association in germplasm collection of sesame (Sesamum indicum L.). Karnataka Journal of Agricultural Sciences 2009; 22(2):252-4.

19. Goudappagoudra $R$, Lokesha $R$, Ranganatha AR Research Note Trait association and path coefficient analysis for yield and yield attributing traits in sesame (Sesamum indicum L.). Electronic Journal of Plant Breeding 2011; 2(3):448-52.

20. Sankar D, Sambandam G, Rao MR, Pugalendi KV. Modulation of blood pressure, lipid profiles and redox status in hypertensive patients taking different edible oils. Clinica Chimica Acta 2005; 355(1-2):97-104. https://doi.org/10.1016/j.cccn.2004.12.009

21. Lalpantluangi, PC, Shah P. Character association and path coefficient analysis in sesame (Sesamum indicum L.) genotypes under foothill condition of Nagaland. The Pharma Innovation 2018; 7(5, Part B), p.82. 